\title{
Cannabis policy reform in Germany: Political and constitutional discourses on decriminalisation and regulation strategies
}

\author{
STEFANIE KEMME* ${ }^{*}$ KRISTIN PFEFFER ${ }^{* *}$, LUISE VON RODBERTUS ${ }^{\star * *}$
}

\section{Introduction}

Numerous German initiatives to liberalise cannabis-related criminal law have arisen against the backdrop of global debates, stimulating reform. Current drug policy is being discussed intensively, including calls to end prohibition of cannabis from wellknown criminal law professors aligning with the resolution of Prof. Dr. med. Lorenz Böllinger. ${ }^{1}$ Advocates cite the benefits of relieving the police and courts to focus their resources on organised crime. Opponents fear legalisation will increase the number of consumers and magnify healthcare costs at the expense of society.

In Western and Central Europe, including Germany, a market for illegal drugs emerged in the late $1960 \mathrm{~s},{ }^{2}$ which has not yet been stabilised politically or socially. The climate favouring drug reforms is a paradigm shift. Liberalisation of drug laws

* Stefanie Kemme, Professor at the University of Applied Police Sciences Hamburg, Germany. Tel. +49 40 / 4286-24419. Email: stefanie.kemme@poladium.de.

** Kristin Pfeffer, Professor at the University of Applied Police Sciences Hamburg and co-founder of the Research Centre of European and German Security Law (FEDS). Tel.: +49 40 /428624416. Email: kristin.pfeffer@poladium.de.

*** Luise v. Rodbertus, Teaching and research associate at the University of Applied Police Sciences Hamburg, Tel. +49 40 / 4286-24451. Email: Luise.vonRodbertus@poladium.de.

1 The resolution is available at http://www.schildower-kreis.de 19. March 2021.

2 Schwind, Kriminologie, Schriftenreihe der Kriminalistik(2013) § 27 para. 10.

This is an Open-access article distributed under the terms of the Creative Commons Attribution 3.0 Unported License (http://creativecommons.org/licenses/ by/3.0/, permitting all use, distribution, and reproduction in any medium, provided the original work is properly cited. 
in the Netherlands, Switzerland, Spain, Belgium, Portugal, the Czech Republic, and several US states has so far not led to an increased drug use as feared. ${ }^{3}$ In 2014, Uruguay legislated to regulate cultivation, sale, and consumption of cannabis to deprive organised crime of the market and to prevent use of harder drugs. ${ }^{4}$ Cannabis has been grown, consumed, and sold in small quantities legally in Canada since 17 October $2018 .{ }^{5}$ In New Zealand a not binding cannabis referendum was held on 17 October 2020 , on the question of whether to legalise the sale, use, possession and production of cannabis. ${ }^{6}$

This paper aims on the one hand, to provide insights into German narcotics law. On the other hand, the political arguments for sticking to prohibition are contrasted with the numerous empirical findings that are now available. The results of the empirical studies now challenge the Federal Constitutional Court and the legislature to review their previous course and possibly break new ground in drug policy. Section 2 outlines the current legal situation following the findings of the German Federal Constitutional Court more than 20 years ago. Section 3 critically reviews the main arguments used so far to justify prohibition, namely the health and social risk assessment and the predicted development of consumption, in terms of their scientific content. Since the new scientific studies may lead to a new constitutional assessment of cannabis use and to a new legal situation in Germany, we trace current political advanced initiatives toward a new cannabis policy in Section 4. In Section 5 we give an overview of 'new facts' presented in a new submission order to the German Federal Constitutional Court in April 2020. Section 6 contains our summary and conclusions.

\section{Current German legal framework}

The German legal framework for drugs and addiction is multi-layered because policy affects many spheres of life. The handling of drugs, dealing and trafficking, medical prescriptions, drug use, and addiction are governed by provisions set at international, European, and national levels. At the national level, a range of parties oversee drug issues. Under Germany's federal structure, they erect cross-sectoral legal conditions concerning addiction and drug policy.

3 Rosmarin and Eastwood, A quiet revolution: Drug decriminalisation policies in practice across the globe (Release 2012) p. 13.

4 Hudak, Ramsey and Walsh Uruguay's cannabis law: Pioneering a new Paradigm, WOLA (2018) https://www.brookings.edu/wp-content/uploads/2018/03/gs_032118_uruguaye28099scannabis-law_final.pdf 19. March 2021.

5 The Cannabis Act (S.C. 2018, c. 16) in Canada. Department of Justice of Canada on Cannabis Legalization and Regulation https://www.justice.gc.ca/eng/cj-jp/cannabis/ 19. March 2021.

6 New Zealand Government: Cannabis legalisation and control referendum https://www.justice. govt.nz/assets/Documents/Publications/Cannabis-Legalisation-and-Control-Bill-ExposureDraft-for-Referendum2.pdf 28. April 2021. 
The driving force behind the restrictive use of cannabis in Germany was international law: The history of the illegalisation of cannabis in Germany begins in 1929, when German Reichstag passed 'The Act on the Trade in Narcotic Drugs' (Opium Law) ${ }^{7}$ in order to implement the so-called 'Geneva Opium Agreement' of $1925^{8}$ signed and ratified by 56 countries. ${ }^{9}$ For the first time in German history the Opium Law mentioned dealing with 'Indian hemp' as a punishable offence. In 1971, Germany's central national legislation was renamed to 'Narcotic Drugs Act' (Betäubungsmittelgesetz; BtMG). ${ }^{10}$ Alongside administrative regulations concerning narcotics trade, the act is significant practically because narcotics offences appear in the daily business of German courts. BtMG determines what substances are narcotics, regulates their trade, and sanctions their handling. Sanctions for violating its provisions include penalties for misdemeanours and crimes, fines for regulatory offences, rehabilitation and prevention measures, and administrative acts such as confiscation. Numerous other laws set criminal provisions and sanctions for drug-related offences, including the German Criminal Code, ${ }^{11}$ German Road Traffic Act, ${ }^{12}$ German Precursors Monitoring Act, ${ }^{13}$ and the German New Psychoactive Substances Act. ${ }^{14}$

Plants and their constituents belonging to genus cannabis are listed in Annex I-\$1 (1) BtMG and are not marketable narcotics. Central forms of action related to cannabis production, sale, and purchase are prohibited. Although consumption is not subject to sanctions, purchase and possession preceding it are subject to sanctions. A permit under $\$ 3$ BtMG can only be granted for scientific or purposes in the public interest. In March 2017, Germany legalised therapeutics containing tetrahydrocannabinol, mainly in the form of the flower or extracts, for patients with for instance chronic pain, multiple sclerosis, and cancer ( $\$ 13 \mathrm{BtMG})$. Legalising medicinal cannabis had a domino effect. Portugal and Denmark followed suit, discussing the legalisation or

7 On 10. December 1929, National Gazette I 1929, Nr. 43 p. 215.

8 International Opium Convention. Geneva, 19 February 1925. https://treaties.un.org/Pages/ ViewDetails.aspx?src=TREATY\&mtdsg_no=VI-6-a\&chapter=6\&clang=_en_19. March 2021.

$9 \quad$ United Nations, Office on Drugs and Crime (UNODC), World Drug Report (2008) p.192 ff.; $<$ https://www.unodc.org/documents/wdr/WDR_2008/WDR_2008_eng_web.pdf> 19. March 2021.

10 The Act on the Trade in Narcotic Drugs in Germany, 22. December 1971, entered into force 01. January 1972, current version 01. March 1994, Federal Law Gazette I pp. 681, 1187. http:// www.gesetze-im-internet.de/btmg_1981/ 19. March 2021.

11 Strafgesetzbuch (StGB) https://www.gesetze-im-internet.de/stgb/ 19. March 2021.

$12 \quad$ Straßenverkehrsgesetz (StVG) https://www.gesetze-im-internet.de/stvg/ 19. March 2021.

13 Grundstoffüberwachungsgesetz (GÜG) https://www.gesetze-im-internet.de/g_g_2008/19. March 2021.

14 Neue-psychoaktive-Stoffe-Gesetz (NpSG) https://www.gesetze-im-internet.de/npsg/ 19. March 2021. 
initiating cannabis-related research. ${ }^{15}$

German legislation allows dismissal of criminal cases against drug users. In this context the most relevant section is $\$ 31 \mathrm{a}$ BtMG,${ }^{16}$ introduced in $1992 .{ }^{17}$ If there is no public interest in prosecution and the offence can be considered minor, $₫ 31 \mathrm{a}$ BtMG allows prosecutors ${ }^{18}$ to dismiss cases without consulting the court. The core consideration in applying $\$ 31 \mathrm{a}$ BtMG is the small amount (geringe Menge) for personal use. 'Small amount' is undefined by the law but specified by the German federal states. The intent is to improve the procedural recruitment options for the public prosecutor's offices by waiving judicial approval.' ${ }^{19}$ The higher regional court case law and prevailing opinion in literature considers an amount of cannabis for a non-dependent user of up to three consumption units as 'small. ${ }^{20}$ In cannabis products up to an active ingredient content of $0.045 \mathrm{~g}$ THC is assumed a small amount. ${ }^{21}$ That corresponds roughly to a gross weight of $6 \mathrm{~g}$ if one assumes in favour of the accused of a very poor quality with an active ingredient content of less than $1 \%{ }^{22}$ However the public prosecutor's offices in the individual federal states assess the 'small amount' of cannabis products differently. The prosecutors can currently dismiss the procedure in any federal state up to a gross weight of $6 \mathrm{~g}$ of the product in accordance with section 31a (1) sentence 1 of the BtMG. Some federal states also allow an adjustment for quantities up to $10 \mathrm{~g}$. Only the federal states of Berlin and Bremen regulation includes the option of setting up to a gross weight of $15 \mathrm{~g}$. That for a 'small amount' with the

15 Aguilar, Gutiérrez, Sánchez and Nougier, Medicinal cannabis policies and practices around the world, International Drug Policy Consortium (2018) http://fileserver.idpc.net/library/ Medicinal\%20cannabis\%20briefing_ENG_FINAL.PDF 19. March 2021.

$16 \S$ 31a Betäubungsmittelgesetz (BtMG)

Refraining from prosecution.

'(1) If the subject matter of the proceedings is an offence pursuant to section 29 subsection 1,2 or 4, the public prosecutor's office may refrain from prosecution if the offender's guilt could be regarded as minor, if there is no public interest in a criminal prosecution and if the offender cultivates, produces, imports, exports, carries in transit, acquires, otherwise procures or possesses narcotic drugs in small quantities exclusively for his personal use. Prosecution should be refrained from if the offender possesses narcotic drugs in a drug consumption room in small quantities exclusively for his personal use, which may be tolerated pursuant to section $10 \mathrm{a}$, without being in possession of a written licence for acquisition.'

17 Weber, Betäubungsmittelgesetz: BtMG [Narcotic Drugs Act] (C.H. BECK 2017) \$ 31a para. 2.

18 Under the same conditions, the court may also refrain from punishing the offender. Section 29 para. 5 Betäubungsmittelgesetz (BtMG): 'The court may waive punishment if the offender cultivates, $[\ldots]$ the narcotics in small quantities for personal consumption only'

19 Bundestag printed matter (BT-Drs.) 12/934, 12. July 1991 http://dipbt.bundestag.de/doc/ btd/12/009/1200934.pdf 19. March 2021.

$20 \quad$ Patzak $2019 \S 31$ a para. 23.

$21 \quad$ Patzak 2019 § 31a para. 22.

22 Patzak, Betäubungsmittelgesetz [Narcotic Drugs Act] in Körner \& Patzak \& Volkmer, (C.H BECK2019) \$31a para. 23. 
meaning of $\$ 31$ a BtMG relevant gross weight of cannabis products can differ by up to $9 \mathrm{~g}$ in a nationwide comparison. ${ }^{23}$ In order to standardise dismissal practice all over Germany the Ministers of the Justice of the federal states are now in favour of a common upper limit for cannabis products, which all states should set at $6 \mathrm{~g} .{ }^{24}$

Germany's ban on cannabis and threat of punishment constitute interference with general freedom of action by adults. In consistent case law of the Federal Constitutional Court, general freedom of action under Article 2 (1) of the Basic Law includes acts that pose health risks. Protection against self-injury can justify interference with adults' general freedom of action only in particularly serious cases. ${ }^{25}$ In 1989 , the Federal Administrative Court decided that the article contravened the comprehensive right of citizenship 'to grant state authorities the power to dictate to the citizen what he has to do in the interests of his own protection. ${ }^{26}$

In March 1994, the Federal Constitutional Court ${ }^{27}$ ruled that criminal cases involving possession, purchase, or import of small amounts of cannabis for personal use must be dismissed because the offender's guilt and harm caused by the offence must be considered trivial. Criminal prosecution in such cases amounts to violations of the principle of proportionality and disrespect for the ultima ratio of criminal law. While defending the constitutionality of BtMG, the Federal Constitutional Court found large differences in dismissal rates unacceptable because they violate rights to equal and non-discriminatory treatment. The Constitutional Court concluded that infringing rights to equal treatment and proportionality could be avoided by implementing consistent non-prosecution policies throughout Germany in cases involving possession of small cannabis quantities for personal use. The 1994 Federal Constitutional Court decision set the standard for prosecution of personal use. It declared that German law enshrines a 'ban on excessive punishment' that had to be observed for minor offences involving personal use of cannabis. of investigations after $\$ 31$ a Narcotics Act for "small amounts" of cannabis for own consumption] (2019) p. 5. https://www.bundestag.de/resource/blob/662498/4660141b7e6a7a291783e0f087f003bb/ WD-3-196-19-pdf-data.pdf 24. August 2020.

24 Decision of the 89th Justice Ministers' Conference, Item II.21 https://www.justiz.nrw.de/JM/ jumiko/beschluesse/2018/Fruehjahrskonferenz_2018/II-21-BW---Geringe-Menge-im-Sinnedes-_-31a-BtMG.pdf 19. March 2021.

25 BVerfG, 12/21/2011, 1 BvR 2007/10 (Germany).

26 BVerwGE 82, p. 45 (48 f.) (Germany).

27 BVerfGE 90, p. 145. A translation of the decision appears at https://germanlawarchive. iuscomp.org/?p=85 19. March 2021. 
The decision further states that in view of the open criminal policy and scientific debate on the dangers of cannabis use and the correct way to combat them, the legislator has to observe and review the effects of existing law, including the experience of others'. ${ }^{28}$ It requested German federal states to assure a 'basically uniform practice of application' and, as a rule, to refrain from prosecution if conditions in $\$ 31 \mathrm{a}$ BtMG apply. In short, the court affirmed cannabis prohibition as constitutional. It would not infringe the principles of proportionality, equality, and personal freedom. ${ }^{29}$ In dissent, Judge Bertold Sommer complained that BtMG was too broad and did not meet the principle of proportionality. ${ }^{30}$

Since 1971 only minor changes have been made to the BtMG. The core component has remained unchanged for 46 years: Cultivation, trading, purchase and possession of cannabis are punishable. The major change today with regard to the German Federal Courts decision in 1994 is the immense expansion of the use of cannabis in therapeutic treatment - especially in the therapeutic and self-medication not accompanied by a doctor. The findings on the effects and areas of application of cannabis in the medical field have now also been recognised by German Courts and lawmakers. On 6. April 2016, the German Federal Administrative Court confirmed a state obligation with regard to the constitutional right to life and physical integrity for medical treatment with cannabis for certain clinical pictures. It also ruled that an exemption for selfcultivation of cannabis should be granted if the narcotic is necessary for medical care and the plaintiff suffering from multiple sclerosis does not have an equally effective and affordable alternative therapy available. In 2017, as a consequence of the developments described, the medical use of cannabis in Germany was partially legalised for seriously ill patients by the law on the amendment of narcotics law and other regulations. ${ }^{31}$ Following a Europe-wide tendering procedure, the contract for the cultivation, harvesting and processing of cannabis for people over 10,400 kg was awarded by the Federal Agency for Medicines and Medical Products (Bundesinstitut für Arzneimittel und Medizinprodukte, BfArM) to two Canadian and one German Company ${ }^{32}$ for four years in April and May 2019. The BfArM assumed that cannabis will be available for government purposes from cultivation in Germany from the fourth quarter of $2020 . .^{33}$

\footnotetext{
28 BVerfGE 90, p. 145 (194) (Germany).

29 BVerfGE 90, p. 145 (Germany).

$30 \quad$ BVerfGE 90, p. 145 (Germany).

31 BGBl. (Federal Law Gazette) Part I, No. 11 (2017) p. 403.

32 Press release 25. May 2019, https://www.bfarm.de/SharedDocs/Pressemitteilungen/DE/2019/ pm4-2019.html 03. September 2020.

33 Press releases 3/19 and 4/19 https://www.bfarm.de/DE/Bundesopiumstelle/Cannabis/ Cannabisagentur/_node.html 19. March 2021.
} 
Doctors wrote almost 60,000 prescriptions in the first quarter of $2019 .{ }^{34}$ However, the health insurance companies refused to cover the costs for every third prescription in $2019 .{ }^{35}$

\section{Arguments in favour of prohibition in the light of empirical studies}

A debate on legalisation has so far been largely avoided by the German Drug Commissioners in the annually published 'report on drugs and addiction. ${ }^{36}$ The arguments for continuing to treat cannabis as an illicit drug are based primarily on the mental and physical impairments, and on the psychosocial and economic consequences of cannabis use. These are also the main arguments of the opponents of liberalisation. Partly the dangers are described dramatically ${ }^{37}$ While only a few years ago the scientific evidence for mental and physical impairments was small and many claims were made on a case-by-case basis, numerous studies of varying quality have appeared. A systematic review (CaPRis-study) commissioned by the Federal Ministry of Health evaluated 2,100 international papers published in a decade. ${ }^{38}$ In the following, the most important political arguments for maintaining criminalisation based on the current state of research will be examined.

34 '60,000 prescriptions in the first quarter of 2019' Fredericke Klein, 20. September 2019, Medical Tribune https://www.medical-tribune.de/medizin-und-forschung/artikel/60-000-rezepte-fuercannabis-im-ersten-quartal-2019-ausgestellt/ 03. September 2020.

35 ' 60,000 prescriptions in the first quarter of 2019’ Fredericke Klein, 20. September 2019, Medical Tribune https://www.medical-tribune.de/medizin-und-forschung/artikel/60-000-rezepte-fuercannabis-im-ersten-quartal-2019-ausgestellt/ 03. September 2020.

36 Drogen- und Suchtbericht der Drogenbeauftragten der Bundesregierung DSB [Drug and addiction report by the Federal Government's Drug Commissioner DSB] (2019, 2020).

37 Habschick, Cannabis: „Legalize it” - not!, 11 Kriminalistik (2014) pp. 627-635; Hambrecht, Schöne neue Welt. Cannabis für alle [Beautiful new world. Cannabis for everyone.], 30 Psychiatrische Praxis (2003) pp. 179-181; Duttge and Steuer, Zur fehlenden Empirie in der Debatte um eine Legalisierung von Cannabis [The lack of empiricism in the debate on the legalisation of cannabis], 33 Medizinrecht (2015) pp. 799-804; Täschner, Gedanken zum Bild des Haschischs in der Öffentlichkeit und zur Legalisierungsdebatte in Verantwortungsvoller Umgang mit Cannabis. - Medizinische, juristische und psychosoziale Perspektiven [Responsible use of cannabis. - Medical, legal and psychosocial perspectives], eds. Duttge et al. (Universitätsverlag Göttingen 2017) pp. 3-10.

38 CaPRis 'Cannabis: Potential und Risiken. Eine wissenschaftliche Analyse ' ['Cannabis: potential and risks. A scientific analysis'] https://www.bundesgesundheitsministerium.de/fileadmin/ Dateien/5_Publikationen/Drogen_und_Sucht/Berichte/Kurzbericht/171127_Kurzbericht CAPRis.pdf 19. March 2021; Hoch, Friemel and Schneider, Cannabis: Potenzial und Risiko. Eine wissenschaftiche Bestandsaufnahme (Springer 2019). 


\subsection{Health risks}

Studies assessed the health risk of cannabis as low, especially in the recreational use of adults, and showed lower health risks than the consumption of alcohol and nicotine. ${ }^{39}$ Chronic cannabis use seems to increase the risk of respiratory symptoms (coughing, wheezing breath, sputum production, chest tightness).$^{40} \mathrm{With}$ regard to other somatic consequences such as cancer and cardiovascular diseases, the evidence is sparse, as most publications do not differentiate, or only insufficiently, between the overlapping effects of tobacco use and cannabis use. ${ }^{41}$ With regard to cognitive deficits of cannabis use (memory, attention processes, executive functions and psychomotor skills), consistent research results are available only with regard to acute cannabis exposure. Concerning the effects of chronic cannabis use on cognition there are heterogeneous findings. ${ }^{42}$ Impaired verbal memory, attention, and some executive functions may persist after prolonged abstinence. ${ }^{43}$ But according to the CaPRis-study, the risk of persistent cognitive and brain functional deficits is rated as rather low. ${ }^{44}$ Findings show an increased vulnerability of adolescents to cognitive disorders through regular cannabis use. ${ }^{45}$ So far, there is not enough research on the extent to which cannabis-associated deficits in cognition are persistent or reversible. ${ }^{46}$

39 Bonnet, Rauschzustände: Risiken und Nebenwirkungen. Im Focus: nicht-medizinisches Cannabis und synthetische Cannabinoide. [Intoxication states: risks and side effects. In focus: non-medical cannabis and synthetic cannabinoids. Addiction treatment.], 17 (02) Suchttherapie (2016) pp. 6170 (61); Bonnet, Specka and Scherbaum, Häufiger Konsum von nicht-medizinischem Cannabis. Gesundheitliche Folgen und Wirkung der Entzugsbehandlung. [Frequent consumption of nonmedical cannabis. Health consequences and effects of withdrawal treatment.], 141 (2) Deutsche Medizinische Wochenschrift (2016) pp. 126-131 (126); Deutsche Gesellschaft für Suchtforschung und Suchttherapie e.V., Stellungnahme zur Legalisierungsdebatte des nichtmedizinischen Cannabiskonsums.' [Statement on the legalisation debate on the non-medical use of cannabis.] (2015). https://www.dg-sucht.de/fileadmin/user_upload/pdf/stellungnahmen/Stellungnahme_ Legalisierungsdebatte_Cannabis_DG-Sucht.pdf 19. March 2021; Gantner, Jenseits der Evidenz: Eine Replik zur Cannabispolitik. [Beyond Evidence: A Replica to the Cannabis Policy.], 17 Suchttherapie (2016) pp. 55-57 (55); Nutt, King and Phillips, on behalf of the Independent Scientific Committee on Drugs, Drug harms in the UK: a multicriteria decision analysis, 376 The Lancet (2010) pp. 1558-1565.

40 Schneider et al., Cannabiskonsum zum Freizeitgebrauch in Cannabis: Potenzial und Risiko. Eine wissenschaftliche Bestandsaufnahme, eds. Hoch, Friemel and Schneider (Springer 2019) pp. 65264 (128).

${ }^{41} \quad$ Kreuter et al., Cannabis-Positionspapier der Deutschen Gesellschaft für Pneumologie und Beatmungsmedizin e.V. (DGP), 70 Pneumologie (2016) pp. 87-97. Schneider et al. 2019 p. 128.

$42 \quad$ Schneider et al. 2019 p. 91.

43 Broyd et al., Acute and Chronic Effects of Cannabinoids on Human Cognition -A Systematic Review, 79 vol. 7 Biol Psychiatry (2016) pp. 557-567.

$44 \quad$ Schneider et al. 2019 p. $91 \mathrm{f}$.

45 Broyd et al. 2016; Fontes et al., Cannabis use before age 15 and subsequent executive functioning, 198 Br J Psychiatry (2011) pp. 442-447.

$46 \quad$ Broyd et al. 2016; Schneider et al. 2019 p. 91. 
A reduced intelligence associated with regular cannabis use could not be consistently demonstrated. ${ }^{47}$ IQ deficits were particularly clear and persistently demonstrated even after a long period of abstinence ( $>1$ year) in consumers who had already shown a dependency before the age of 18 . No irreversible IQ reduction was found in firsttime users after the age of $18 .^{48}$ Studies increasingly suggest that moderate cannabis use has no negative effects on the intelligence of adolescents. ${ }^{49}$ However, the chronic cannabis use is associated with structural changes in brain regions with a high density of CB1-receptors - especially amygdala and hippocampus, structures responsible for memory formation. ${ }^{50}$

Studies that establish a link between cannabis use and psychotic disorders are inconsistent. ${ }^{51}$ Kraan et al. ${ }^{52}$ found that even among persons who fall into the highrisk group for psychoses, there is no statistically significant long-term association between cannabis use and increased incidence of disease. Nevertheless, an earlier age at onset of cannabis use ${ }^{53}$ and higher levels of cannabis use ${ }^{54}$ seem to increase the risk for development of psychosis related to cannabis use. Study results indicate a doseand concentration-dependent relationship..$^{55}$ Also, the risk of psychotic disorders

47 CaPRis 2017 p. 2.

48 Meier et al., Persistent cannabis users show neuropsychological decline from childhood to midlife, 190 (40) Proc Natl Acad Sci US (2012) pp. 2657-2664.

49 Mokrysz et al., Are IQ and educational outcomes in teenagers related to their cannabis use? A prospective cohort study, 30 (2) J Psychopharmacol (2016) pp. 159-168; Jackson et al., Impact of adolescent marijuana use on intelligence: Results from two longitudinal twin studies. 113(5) Proc Natl Acad Sci USA (2016) pp. 500-508.

$50 \quad$ Cf. CaPRis 2017 p. 3; Schneider et al. 2019 p. 128.

${ }^{51} \quad$ E.g. Bonnet et al. 2016; Kraan et al., Cannabis use and transition to psychosis in individuals at ultra-high risk: Review and meta-analysis, 46 (4) Psychol Me (2015) pp. 673-681; Power et al., Genetic predisposition to schizophrenia associated with increased use of cannabis, 19 (119) Molecular psychiatry (2014) pp. 1201-1204; Marconi et al., Meta-analysis of the association between the level of cannabis use and risk of psychosis, 42(5) Schizophr Bull (2016) pp. 12621269.

$52 \quad$ Kraan et al. 2015.

53 Hanna and Perez, Ghose Cannabis and development of dual diagnoses: A literature review, 43(4) Am J Drug Alcohol Abuse (2017) pp. 442-455.

${ }_{54}$ Manrique-Garcia et al., Cannabis, schizophrenia and other non-affective psychoses: 35 years of follow-up of a population-based cohort, 42(6) Psychol Med (2012) pp. 1321-1328; Marconi et al. 2016.

55 Marconi et al. 2016; Wotjak, Role of endogenous cannabinoids in cognition and emotionality, 5(7) Mini Rev Med Chem (2005) pp. 659-670; Zanettini et al., Effects of endocannabinoid system modulation on cognitive and emotional behavior, 5(57) Front Behav Neurosci (2011). 
seems to be increased for persons with genetic predispositions. ${ }^{56}$ However, the causal role of cannabis use in the development of psychotic disorders has not yet been clarified.$^{57}$ In general, a psychotic disorder is to be regarded as a multifactorial event in whose development not only environmental influences, but also genetic factors play an important role. ${ }^{58}$

An increased risk for mental disorders such as anxiety and depression is not proven by all studies; findings are also inconsistent. ${ }^{59}$ Some studies find no longitudinal associations between cannabis use and anxiety or depression. ${ }^{60}$ Meta-analyses and systematic reviews concluded that there was a modestly increased risk of depressive and anxiety disorders, ${ }^{61}$ and a greater risk of bipolar disorder. ${ }^{62}$

Overall, inconsistent or incomplete findings require methodologically reliable longitudinal studies. ${ }^{63}$ Still it's uncertain whether cannabis plays a causal role in the onset and persistence of mental disorders, adolescents with symptoms of mental disorders are more likely to use cannabis and alcohol and to develop problematic patterns of use of both drugs. ${ }^{64}$ In general, mental disorders are usually the result of multifactorial events rather than a single trigger. ${ }^{65}$

56 Radhakrishnan, Wilkinson and D'Souza, Gone to pot - a review of the association between cannabis and psychosis, (5) Frontiers in psychiatry (2014) pp. 1-24 (9); Van Winkel and Kuepper, Epidemiological, Neurobiological, and Genetic Clues to the Mechanisms Linking Cannabis Use to Risk for Nonaffective Psychosis. 10(1) Annual Review of Clinical Psychology (2014) pp. 767791 (784); Power et al. 2014; Verweij et al. 2017.

57 Havemann-Reinecke et al., Zur Legalisierungsdebatte des nichtmedizinischen Cannabiskonsums [On the legalisation debate of non-medical cannabis use], 88 Nervenarzt (2016) pp. 291-197; Schneider et al. 2019 p. 212.

$58 \quad$ Schneider et al. 2019 p. 219.

59 Blanco et al., Cannabis Use and Risk of Psychiatric Disorders. Prospective Evidence From a US National Longitudinal Study, 73(4) JAMA Psychiatry (2016) pp. 388-395; Danielsson et. al., Cannabis use, depression and anxiety: A 3-year prospective population-based study, 193 Journal of Affective Disorders (2016) pp. 103-108; Horwood et al., Cannabis and depression: An integrative data analysis of four Australasian cohorts, (126) Drug and Alcohol Dependence (2012) pp. 369-378.

60 e.g. Blanco e al. 2016; Danielsson et al. 2016.

${ }_{61}$ Moore et al., Cannabis use and risk of psychotic or affective mental health outcomes: a systematic review, 370(9584) Lancet (2007) pp. 319-328; Kedzior and Laeber, A positive association between anxiety disorders and cannabis use or cannabis use disorders in the general populationA meta-analysis of 31 studies, (14) BMC Psychiat (2014); Lev-Ran et al., The association between cannabis use and depression: a systematic review and meta-analysis of longitudinal studies, (44) Psychological Medicine (2013) pp. 797-810.

$62 \quad$ Schneider et al. 2019 p. 232.

63 See also CaPRis 2017 p. 2.

64 Hoch et al. 2019.

65 CaPRis 2017. 
A further argument for maintaining the criminalisation of cannabis is the psychological and physical dependence resulting from its use. ${ }^{66}$ Cannabis Use Disorders (CUD), one of the psychiatric diagnoses included in the Diagnostic and Statistical Manual of Mental Disorders, is generally understood as abuse or dependence. DSM-V, published in 2013, shifted away from the abuse/dependence paradigm toward a more dimensional scale that incorporates level of severity into its measurement of the syndrome, essentially combining the abuse and dependence criteria into one set for a diagnosis of disorder. ${ }^{67} \mathrm{CUD}$ is defined as cannabis use that is associated with clinically significant problems ranging from mild to severe, including inability to stop using it despite psychosocial/ medical problems, the presence of craving, the need to use larger amounts to obtain the same effect (tolerance), and/or the onset of symptoms when its use is stopped (withdrawal) ${ }^{68}$ In the case of physical dependence, the body reacts with withdrawal symptoms. A first characteristic of physical dependence is the development of tolerance and the resulting increase in dosage. Cannabis withdrawal is a valid clinical syndrome (such as sweating, trembling, restlessness, irritability, peace) that emerges following abrupt cessation of frequent cannabis use. ${ }^{69}$ Physical withdrawal is comparably mild..$^{70}$ Nevertheless, the addictive potential of cannabis is indisputably lower $(6.2 \%)$ than that of legal drugs such as alcohol (11.2\%) or nicotine $(36.0 \%) .^{71}$

Particular risk factors for the development of cannabis-related disorders including dependence are male gender, intensive use patterns, co-use with tobacco and early age at onset. ${ }^{72}$ In general, for all drugs, the early onset of substance use is related to Disorders, eds. Montoya and Weiss (Springer 2019) pp. 7-11 (8); Montoya and Weiss, Cannabis Use Disorder (Springer 2019) pp. 1-6.

$68 \quad$ Montoya and Weiss 2019 p. 2.

69 Schlienz and Vandrey, Cannabis Withdrawal in Cannabis Use Disorder, eds. Montoya and Weiss (Springer 2019) pp. 93-102 (99).

70 Soyka, Preuss and Hoch, Cannabisinduzierte Störungen [Cannabis-induced disorders], (88) Nervenarzt (2017) pp. 311-325 (311, 323).

71 Behrendt et al., Transitions from first substance use to substance use disorders in adolescence: is early onset associated with a rapid escalation?, (99) Drug and Alcohol Dependence (2009) pp. 6878. Scharnhorst and Honecker, Normenkontrollantrag zur Vorlage beim Bundesverfassungsgericht [Norm control application for submission to the Federal Constitutional Court (German Hemp Association] (Deutscher Hanfverband, 2019) p. 20.

72 CaPRis 2017; Hoch et al. 2019. 
an elevated risk of substance use disorder. ${ }^{73}$ Youth under the age of 18 are four to seven times more likely to develop CUD than adults. ${ }^{74}$ Studies show that the early use of cannabis poses a risk for adolescents with regard to the development of brain functions, ${ }^{75}$ impulse control, affect control, control of attention and concentration, memory, verve and social-organisational skills. ${ }^{76}$ Cannabis use during adolescence is associated with worse mental health. ${ }^{77}$ Also the relative risk of cannabis dependence is higher for adolescents. ${ }^{78}$ However, the increased demand for treatment ${ }^{79}$ cannot be cited as evidence of the particular risk potential among young people. The treatment figures initially only indicate that an addiction aid system with cannabis-specific services has been established in Germany over the last 10 years that is also being used..$^{80}$

\subsection{Social risks}

Furthermore, it is argued that regular cannabis use leads to psychosocial problems for adolescents including an increase in the frequency of early school leaving, less university attendance and therefore fewer academic degrees ${ }^{81}$ Indeed, meta-analyses and systematic reviews show that cannabis use is associated with higher school drop-

73 Blanco et al. 2016; Chen, O'Brien and Anthony, Who becomes cannabis dependent soon after onset of use? Epidemiological evidence from the United States: 2000-2001, 79(1) Drug and Alcohol Dependence (2005) pp. 11-22; Chen, Storr and Anthony, Early-onset drug use and risk for drug dependence problems, (34) Addict Behav (2009) pp. 319-322; DeWit et al., Age at first alcohol use: a risk factor for the development of alcohol disorders, (157) Am. J. Psychiatry (2000) pp. 745-750; Grant and Dawson, Age at onset of drug use and its association with DSM-IV drug abuse and dependence: results from the National Longitudinal Alcohol Epidemiologic Survey, (10) Journal of Substance Abuse (1998) pp. 163-173.

74 Winters and Lee, Likelihood of developing an alcohol and cannabis use disorder during youth: association with recent use and age, (92) Drug and Alcohol Dependence (2008) pp. 239-247.

75 Weiss et al., Building smart cannabis policy from the science up, (92) International Journal of Drug Policy (2017) pp. 39-49; Lubman, Cheetham and Yucel, Cannabis and adolescent brain development, (148) Pharmacology \& Therapeutics (2015) pp. 1-16; Orr et al., Grey matter volume differences associated with extremely low levels of cannabis use in adolescence, 39(10) Journal of Neuroscience (2019) pp. 1817-1827.

76 Bonnet et al. 2016 p. 127; Havemann et al. 2016; Marconi et al. 2016; van Winkel and Kuepper 2014 pp. 771-772.

77 Silins et al., Young adult sequelae of adolescent cannabis use: an integrative analysis, (1) Lancet Psychiatry (2014) pp. 286-293; Townsend et al. 2007; Gobbi et al. 2019.

78 NAC 2017; Chen et al. 2005; 2009.

79 E.g. Bonnet and Scherbaum, Cannabisbezogene Störungen Teil I: Pharmakologie, Epidemiologie und Therapieverfahren [Cannabis-related disorders Part I: Pharmacology, Epidemiology and Therapeutic Procedures], (78) Fortschritte der Neurologie Psychiatrie (2010) pp. 297-305 (299).

80 See Gantner 2016 pp. 55, 56; Tossmann and Gantner, Frühintervention, Beratung und Behandlung bei Cannabisstörungen [Early intervention, consultation and treatment for cannabis disorders], (17) Suchttherapie (2016) pp. 85-89 (85).

$81 \quad$ DSB, 2018; DSB 2019. 
out rates and lower rates of University attendance and the successful completion of studies. ${ }^{82}$ But similar to the development of mental disorders, the question of causality between cannabis use among young people and lower educational successes cannot be clarified. ${ }^{83}$

Also, the argument that prohibition protects the young against developing criminal behaviour and the use of hard drugs remains scientifically unproven. The assumption that cannabis is a 'gateway drug' to 'hard' drugs is unfounded. It has been proven that hard drug users usually first used 'softer' cannabis products, ${ }^{84}$ but this causal chain cannot be proven in the opposite way. The number of cannabis users who later switch to hard drugs is low. ${ }^{85}$ On the basis of the study 'Monitoring the future', alcohol is the 'gateway drug' and is consumed before cigarettes and cannabis. ${ }^{86}$ The causal mechanisms of cannabis as gateway drug remain unclear. Nevertheless, prohibitionists seem influenced by the 'gateway drug' argument. ${ }^{87}$ But even the Federal Constitutional Court rejected this argument in the 1994 decision.

Studies of links between cannabis and crime yield no consistent results. Crosssectional studies that could prove a connection cannot make causal claims ${ }^{88}$ Bryan,

82 Horwood et al., Cannabis use and educational achievement: findings from three Australasian cohort studies, 110(3) Drug and Alcohol Dependence (2010) pp. 247-253; Macleod, The psychosocial consequences of drug misuse: A systematic review of longitudinal studies, (Suppl1) Drugs Educ Prevent Policy 12 (2005) pp. 85-89; Silins et al. 2014.

$83 \quad$ Schneider et al. 2019 p. 138.

${ }^{84}$ E.g. Fergusson, Boden and Horwood 'Cannabis use and other illicit drug use: testing the cannabis gateway hypothesis', (101) Addiction (2006) pp. 556-569.

85 Kreuzer and Wille, Drogen - Kriminologie und Therapie [Drugs - criminology and therapy.] (Hermann Luchterhand Verlag 1998) p. 29; Krumdiek, Cannabis sativa L. und das Aufleben alter Vorurteile [Cannabis sativa L. and the revival of old prejudices.], Neue Zeitschrift für Strafrecht (2008) pp. 437-444 (441); Stöver and Plenert, Entkriminalisierung und Regulierung. Evidenzbasierte Modelle für einen alternativen Umgang mit Drogenhandel und -konsum. [Decriminalization and regulation. Evidence-based models for an alternative approach to drug trafficking and consumption], (8) Friedrich-Ebert-Stiftung (2013) http://library.fes.de/pdf-files/ iez/10159.pdf 1. March 2019

86 Kirby and Barry, Alcohol as a gateway drug: a study of US 12th graders, 82(8) Journal of School Healt (2012) pp. 371-379 (372 f.).

87 Duttge and Steuer 2015 p. 801; Duttge and Steuer, Legalisierung von Cannabis: Verkommt Deutschland $\mathrm{zu}$ einer berauschten Gesellschaft? [Legalisation of cannabis: Does Germany turn into an intoxicated society?], (6) Zeitschrift für Rechtspolitik (2014) pp. 181-185; Duttge and Steuer 2014 p. 183; Habschick 2014 p. 629; Holm-Hadulla, Cannabis, ein harmloses Genussmittel? - Die Verleugnung körperlicher, psychischer und sozialer Risiken in Werbung und populären Medien [Cannabis, a harmless stimulant? - The denial of physical, psychological and social social risks in advertising and popular media] in Duttge et al. (2017) pp. 13-26 (21).

88 Hoaken and Stewart, Drugs of abuse and the elicitation of human aggressive behavior, 28 (9) Addictive Behaviors (2003) pp. 1533-1554. 
Del Bono and Pudney ${ }^{89}$ found that people who use cannabis as their only drug, without the co-use of other substances, do not commit crimes generated by the drug. Some longitudinal studies do associate increased risk of violence with longterm cannabis use, ${ }^{90}$ others don't. ${ }^{11}$ Despite inconsistent international findings, it is certain that cannabis use occurs predominantly in combination with alcohol and tobacco. ${ }^{92}$ Moreover, it is confirmed that early alcohol consumption leads to later increased delinquency, in particular to violent. ${ }^{93}$ But no drug in itself monocausal leads to criminality; drug use is embedded in complex psychosocial conditions. ${ }^{94}$ This statement is important, especially with regard to violent offenses, whose complex origins are well researched in early socialization environments shaped by violence.

89 Bryan, Del Bono and Pudney, Drug-related crime, No. 2013-08 ISER Working Paper Series (2013), University of Essex, Institute for Social and Economic Research (ISER), Colchester.

90 Schoeler et al., Continuity of Cannabis use and violent offending over the life course, 46(8) Psychological Medicine (2016) pp. 1663-1677 (1673).

${ }_{91} \quad$ Baier, Schepker and Bergmann, Macht Kiffen friedlich und Saufen aggressiv?' [Makes smoking Marijuana peaceful and drinking aggressively?], 27(4) Zeitschrift für Jugendkriminalrecht und Jugendhilfe (2016) pp. 324-332; Green et al., Does heavy adolescent marijuana use lead to criminal involvement in adulthood? Evidence from a multiwave longitudinal study of urban African Americans, 112 (1) Drug and Alcohol Dependence (2010) pp. 117-125 (123).

92 ESPAD Group (2016). ESPAD Report 2015: Results from the European School Survey Project on Alcohol and Other Drugs. Publications Office of the European Union, Luxembourg (2015).

93 Baier et al. 2016; Maldonado-Molina, Reingle and Jennings, Does alcohol use predict violent behaviors? The relationship between alcohol use and violence in a nationally representative longitudinal sample, 9(2) Youth violence and juvenile justice (2011) pp. 99-111.

94 Kreuzer, Endstation Sucht? - Wege aus der Sucht? [Last Stop Addiction? - Ways out of addiction?], in Mehrfach Auffällige - Mehrfach Betroffene. Erlebnisweisen und Reaktionsformen [Multiple Offenders - Multiple Victims. Experiences and forms of reaction], eds. Deutsche Vereinigung für Jugendgerichte und Jugendgerichtshilfen e.V. Schriftenreihe des DVJJ, Bd. 18 (Forum Verlag 1900) pp. 276-297; Kreuzer, Drogen, Kriminalität und Strafrecht [Drugs, crime and criminal law.], (3) Zeitschrift für Jugendkriminalrecht und Jugendhilfe (2005) pp. 235-241; Kreuzer, Zusammenhänge zwischen Drogen und Kriminalität [Connections between drugs and crime], (9) Forensische Psychiatrie, Psychologie, Kriminologie (2015) pp. 3-9; Kreuzer, Römer-Klees, and Schneider, Drugs and Delinquency: Some results of a current selfreport study of university students and of recent in-depth interviews with drug addicts in Drug Addiction Treatment Research. German and American Perspectives, eds. Bühringer and Platt (Krieger 1992) pp. 409-431. 


\subsection{Protection of children and adolescents - prevention of higher consumption}

According to a rating of European addiction experts, ${ }^{95}$ the severity of physical, mental and social impairments caused by cannabis was rated 18 on a scale from 0 (no harm) to 100 (severe harm), putting cannabis in 8th place compared with other common drugs (behind alcohol, heroin, crack cocaine, methamphetamine, tobacco and amphetamine, but before GHB, methadone, benzodiazepines, ecstasy and hallucinogens).

Although cannabis is a relatively harmless drug, advocates of prohibition argue with the general danger of the drug. ${ }^{96}$ Although this cannot be generally claimed, as the results show, there is agreement that children and young people are particularly vulnerable groups. But whether effective protection can be achieved through criminalisation or regulation, or how young people and children can be most effectively discouraged from consuming cannabis, is again highly controversial. Probably the most important argument against further-reaching reforms is that a regulated market sends the wrong signal and seduces children and young people to use cannabis. ${ }^{97}$

Two basic assumptions are made. It is claimed that prohibition has a direct positive effect on consumption rates, so that (1) a higher availability of cannabis and (2) a subsequent increase in consumption rates in the course of regulation is assumed..$^{98}$

Cannabis is the most frequently used drug. In 2018 there were 250 million cannabis users worldwide and 31 million in Europe. It is estimated that 91.2 million adults in the European Union (between 15 and 64 years) or $27.4 \%$ of this age group during their lifetime have tried cannabis. About 17.5 million young adults (between 15 and

95 Amsterdam et al., European rating of drug harms, 29(6) J Psychopharmacol (2015) pp. 655-660.

96 Sueddeutsche.de am 19.06.2020. Daniela Ludwig warnt vor Verharmlosung von Cannabiskonsum [Daniela Ludwig warns against trivialising the use of cannabis]. https://www. sueddeutsche.de/gesundheit/gesundheit-berlin-daniela-ludwig-warnt-vor-verharmlosung-voncannabiskonsum-dpa.urn-newsml-dpa-com-20090101-200619-99-482729 19. March 2021.

97 DAZ.online am 29.07.2019. Spahn: Cannabis-Legalisierung wäre das falsche Signal [Spahn: Cannabis legalisation would be the wrong signal] unter https://www.deutsche-apothekerzeitung.de/news/artikel/2019/07/29/spahn-cannabis-legalisierung-waere-das-falsche-signal 19. March 2021.

$98 \quad$ E.g. Duttge and Steuer, 2014; Hambrecht 2003; Thomasius, Gesundheitliche Auswirkungen von Cannabismissbrauch bei Jugendlichen undjungen Erwachsenen, in Duttge et al. (2017) pp. 27-46 (39). Weber, Freigabe illegaler Drogen: Ethisch geboten oder unverantwortlich? - Kontra [Illegal drug release: ethically required or irresponsible? - Contra], (9) Suchttherapie (2008) pp. 170-176. 
34 years) or $14.4 \%$ of this age group have tried cannabis in the last twelve months. ${ }^{99}$ $19 \%$ of all students between 15 to 16 years old have tried cannabis at least once. ${ }^{100}$

About a quarter of adults (between 15 and 64 years) in Germany (27.2\%) report having used cannabis at least once in their lives. ${ }^{101}$ The prevalence of cannabisrelated disorders in 2018 is relatively low among 18 to 59-year-old men (abuse 0.7\%; dependence $0.9 \%$ ) and women (abuse $0.4 \%$; dependence $0.3 \%$ ). ${ }^{102}$ For adolescents, the values vary depending on the sample and the age group studied. Approximately each tenth young person between 12 and 17 years has already tried Cannabis at least once in his life. ${ }^{103}$ In the age group of young adults (between 18 and 25 years) the lifetime prevalence rises clearly to $46.4 \%$. Of these, only a few are regular users (more than ten times in the last 12 months), as can be seen from the prevalences for adolescents (2.0\%) and young adults (8.0\%). ${ }^{104}$ If one considers the development of the consumption in the last years with young people and young adults, then highest prevalences were to be registered in the year 2004: afterwards rates decreased and rise since 2011 with young people, since 2016 with young adults again. Currently, the use experience of adolescents and young adults with cannabis is still below the high level of $2004 .{ }^{105}$

In order to obtain indications of whether drug policy approaches are related to availability and consumption, values from individual countries can be compared. In Europe, the lifetime prevalence rate of 15-year-old German girls and boys (15\% and $18 \%$, respectively) falls in the mid-range behind France, Switzerland, Italy, Belgium (French), England, and Spain (Health Behaviour in School-aged Children

EMCDDA (European Monitoring Centre of Drugs and Drug Addiction) and Europol (2019). EU Drugs Markets Report. Gemeinsame EMCDDA-Europol-Veröffentlichungsreihe. Amt für Veröffentlichungen der Europäischen Union, Luxemburg, p. 93.

EMCDDA (European Monitoring Centre for Drugs and Drug Addiction) auf Basis der Daten der ESPAD Studie 2015 (European School Survey Project on Alcohol and Other Drugs); EMCDDA 2019.

$101 \quad$ EMCDDA 2019 p. 44.

102 Seitz et al., Trends des Substanzkonsums und substanzbezogener Störungen. Auswertung des Epidemiologischen Suchtsurveys von 1995 bis 2018, (116) Dtsch Arztebl Int, (2019) pp. 585591.

103 Orth and Merkel, Die Drogenaffinität Jugendlicher in der Bundesrepublik Deutschland 2019. Rauchen, Alkoholkonsum und Konsum illegaler Drogen: aktuelle Verbreitung und Trends. BZgA-Forschungsbericht (Bundeszentrale für gesundheitliche Aufklärung 2020) p. 58.

$104 \quad$ Ibid.

105 Ibid. p. 62. 
Study [HBSC Survey] of the World Health Organization). ${ }^{106}$ Large differences in consumption rates and patterns emerge within Europe and North America.

The liberalisation of the Dutch drug law took place as early as 1976. Ownership, acquisition, trade, and production are not legalised, but retailing in coffee shops under strict conditions is not prosecuted. Adolescents are prohibited from coffee shops. Studies have sought evidence of increased consumption in the Netherlands, which has pursued liberal cannabis policies for 40 years. So far there is no evidence that decriminalisation of cannabis use led to an increase in use. ${ }^{107}$ Lifetime prevalences of 15 -year-olds ${ }^{108}$ (both $15 \%$ girls and $18 \%$ boys) and 15 to 64 -year-olds ${ }^{109}(27.2 \%$ Germany vs. $26.6 \%$ Netherlands) stand at German levels.

Already since June 2003, the possession of cannabis for personal use is no longer prosecuted in Belgium. A fine will be imposed on persons carrying less than 3g. ${ }^{110}$ Related to the survey year 2013, the consumption prevalence of young adults aged 15 to 34 years in Belgium was $10.1 \%$ and thus below the level of Germany of $13.3 \% .{ }^{111} \mathrm{Per}$

106 WHO, Growing up unequal: gender and socioeconomic differences in young people's health and well-being. Health Behaviour in School-aged Children (HBSC 2016) p. 172 http://www. euro.who.int/en/health-topics/Life-stages/child-and-adolescent-health/health-behaviour-inschool-aged-children-hbsc/growing-up-unequal.-hbsc-2016-study-20132014-survey 19. March 2021.

107 Kilmer, Do Cannabis Possession Laws Influence Cannabis Use? in Ministry of Public Health of Belgium, eds. Cannabis 2002 report: a joint international effort at the initiative of the Ministers of Public Health of Belgium, France, Germany, The Netherlands, Switzerland: technical report of the scientific conference (2002) pp. 101-123. Brussels: Belgian Ministry of Public Health (2002) p.105. https:/www.stop-cannabis.ch/images/stories/documents_stop_ cannabis/cannabis2002report.pdf; Neu, Betrachtungen zu einer möglichen Neuregulierung der Cannabispolitik in Deutschland unter Berücksichtigung der Erfahrungen aus den Niederlanden und Colorado [Discussing possible new regulations in German cannabis policy with special regard to the experiences in the Netherlands and Colorado], 86(7) Fortschritte der Neurologie Psychiatrie (2018) pp. 428-433; Reinarman, Cohen and Kaal, The Limited Relevance of Drug Policy: Cannabis in Amsterdam and in San Francisco, 94(5) American Journal of Public Health (2004) pp. 836-842; Reuband, Drogenkonsum und Drogenpolitik. Deutschland und die Niederlande im Vergleich. [Drug use and drug policy. Germany and the Netherlands in comparison.] (Westdt. Verlag 1992) p. 43; Simons-Morton et al., Cross-national comparison of adolescent drinking and cannabis use in the United States, Canada, and the Netherlands, 21(1) The International Journal of Drug Policy (2010) pp. 64-69.

108 WHO 2016 p. 172.

109 EMCDDA 2019 p. 93.

110 Deutscher Bundestag, Legalisierung von Cannabis Auswirkungen auf die Zahl der Konsumenten in ausgewählten Ländern [Legalisation of cannabis Effects on the number of users in selected countries] (2019) p. 6.

111 EMCDDA 2019 p. 93. 
the HBSC Survey, ${ }^{12}$ Flemish Belgium has rates of lifetime prevalence at the same level as in Germany ( $18 \%$ for 15 year-old males and $14 \%$ for 15 year-old females). Lifetime prevalence among Belgian adolescents aged 15 and 16 years has fallen significantly since the liberalisation of Belgian drug legislation, from 31\% in 2003 to $18 \%$ in $2015 .{ }^{113}$

Per the HBSC Survey, France, where cannabis use is banned but barely prosecuted, has the highest rates of lifetime prevalence (29\% for 15 year-old males and $26 \%$ for 15 year-old females). ${ }^{114}$ In the Czech Republic, where consumption of soft and hard drugs is largely an administrative offence, cannabis consumption rates were $23 \%$ among 15 year-old girls and boys, but no higher than in France. ${ }^{115}$

In Portugal, drug possession was decriminalised as early as 2001. Even the possession of a small amount of so-called hard drugs was no longer considered a criminal offence, but was classified as an administrative offence. Portugal's decriminalisation model was associated with decreasing rates among young people. ${ }^{116}$ Later, the prevalence of consumption had fallen back to approximately the level of $2001 .{ }^{117}$ Compared to other European countries, however, consumption rates in Portugal are very low: in 2013/14 about $10 \%$ and $13 \%$, respectively, among 15 -year-old girls and boys. ${ }^{118}$ The 12 -months prevalence for 15-34 year olds lies at $8 \%$ in 2016. ${ }^{119}$ These and other improvements in Portugal's drug situation (declining rates of intensive use and drug-related harm) are not only attributed to decriminalisation but also to the Commission for Dissuasion of Drug Addiction (CDT), health improvements and harm minimisation, so it is assumed that the reform was successful. ${ }^{120}$

112 WHO 2016 p. 172.

113 Deutscher Bundestag 2019 p. 7; EMCDDA 2019 p. 93.

114 WHO 2016 p. 172.

115 Ibid.

116 Hughes and Stevens, What Can We Learn From The Portuguese Decriminalization of Illicit Drugs?, 50(6) British Journal of Criminology (2010) pp. 999-1022 (1017).

117 Murkin, Drug decriminalisation in Portugal: setting the record straight, Transform (2014). http://www.tdpf.org.uk/resources/publications/drug-decriminalisation-portugal-setting-recordstraight 01. March 2019.

$118 \quad$ WHO 2016 p. 172.

119 EMCDDA 2019 p. 93.

$120 \quad$ Hughes and Stevens 2010 p. 1917; Hughes and Stevens, A resounding success or a disastrous failure: Re-examining the interpretation of evidence on the Portuguese decriminalisation of illicit drugs, (31) Drug and Alcohol Review (2012) pp. 101-113 (112 f.); Murkin 2014 p. 3; Murkin, Will drug use rise? Exploring a key concern about decriminalising or regulating drugs, Transform (2016) https://transformdrugs.org/wp-content/uploads/2020/07/Use-report-2016. pdf; Streck, 15 Jahre entkriminalisierte Drogenpolitik in Portugal, Telepolis (2016) under https:// www.heise.de/tp/features/15-Jahre-entkriminalisierte-Drogenpolitik-in-Portugal-3224495.html 31. August 2020. 
Indications of the effects of a regulated market are available in the US, but data provide limited evidence because adolescents under 21 are subject to total prohibition in all states that have legalised cannabis. ${ }^{121}$ Results from the 2018 National Survey of Drug Use and Health Substance Abuse by the Mental Health Services Administration ${ }^{122}$ show despite legalisation in further US states ${ }^{123}$ that cannabis use (12-months prevalence) among 12 to 17 year-olds in 2018 was lower than the percentages in 2002-2004 and in 2009-2013, but it was similar to the percentages in 2005-2008 and in 2014-2017. Consumption has increased only among those over 26 and little among those 18 to 25. ${ }^{124}$ Colorado, the first state to legalise marijuana by referendum in 2012 , did not exhibit any differential change in perceived harmfulness or past-month adolescent marijuana use following legalisation. ${ }^{125}$

Canada decriminalised cannabis use in October 2018 with the so-called Cannabis Act (C4525). This legalised the possession of a maximum of 30 grams for adults. Canada has established a national statistical system to measure the social and economic impact of the legalisation of cannabis. The National Cannabis Survey (NCS) has been conducted since February 2018 so the first data on the consumption

121 Barsch, Effekte und Nebeneffekte der Umsetzung der Regulierung von Marihuana in den USA: Stand Herbst 2016. [Effects and side effects of the implementation of the regulation of marijuana in the USA: Status autumn 2016] in akzept e.V. Bundesverband für akzeptierende Drogenarbeit und humane Drogenpolitik, Deutsche AIDS-Hilfe, JES e.V. Bundesverband [Federal Association for Acceptable Drug Work and Human Drug Policy, German AIDS Aid, JES e.V. Bundesverband], eds. 5. Alternativer Drogen- und Suchtbericht 2018 (Alternative Drug and Addiction Report 2018) pp. 67-75 (71).

122 SAMHSA (Substance Abuse and Mental Health Services Administration) (2019). Key substance use and mental health indicators in the United States: Results from the 2018 National Survey on Drug Use and Health (NSDUH) (HHS Publication No. SMA 17-5044, NSDUH Series H-52). Rockville, MD: Center for Behavioral Health Statistics and Quality, Substance Abuse and Mental Health Services Administration. https://www.samhsa.gov/data/ 01. September 2020 p. 14.

123 The District of Columbia and 11 states -- Alaska, California, Colorado, Illinois, Maine, Massachusetts, Michigan, Nevada, Oregon, Vermont and Washington -- have adopted the most expansive laws legalising marijuana for recreational use: https://www.governing.com/gov-data/ safety-justice/state-marijuana-laws-map-medical-recreational.html 31. August 2020.

$124 \quad$ SAMHSA 2019 p. 14.

125 Cerdá, M. et al., Association of State Recreational Marijuana Laws With Adolescent Marijuana Use, 171(2) JAMA Pediatric (2017) pp. 142-149. HIDTA (Rocky Mountain High Intensity Drug Trafficking Area) (2019). The legalization of marijuana in Colorado: The Impact. https://rmhidta. org/files/D2DF/FINAL-Volume6.pdf. 31.08.2020. Tormohlen et al., Changes in prevalence of marijuana consumption modes among Colorado high school students from 2015 to 2017, 173(10) JAMA Pediatric (2019) pp. 988-989. 
of cannabis are available. The changes in consumption were very moderate. ${ }^{126}$ Overall cannabis use had increased from $14.9 \%$ (2018) to $16.8 \%$ (2019), particularly among males and adults aged 25 and older. Daily or almost daily use remained stable at $6.0 \%$, as did the prevalence of driving within 2 hours of consumption (13.2\%). Canadians report increasingly to obtain cannabis from legal sources instead of illegal sources or relying on friends/family. NCS study suggests that use among Canadian youth has not increased. ${ }^{127}$

Hints of declining consumption rates by US and Canadian adolescents could indicate reduced availability. About one-third of 16-year-olds in 35 European countries report cannabis is readily or very readily available. ${ }^{128}$ Availability rates span $5 \%$ to $50 \%$. Looking again at European Countries with different drug policies, $41 \%$ of French, $42 \%$ of Dutch, $50 \%$ of Czech, and $31 \%$ of Portuguese adolescents indicate easy availability. As shown, however, consumption among adolescents diverges significantly, and correlations between drug policy and availability (the more repressive the lower) are not provable. Also, availability of a drug is embedded amid complex conditions. For example, young people in a prohibitive model may find it easier to obtain drugs because prohibition triggers black markets. Contrary to expectations of prohibitionists, prices in Colorado and Washington have fallen since legalisation, and prison sentences for distributing unlicensed cannabis have declined facts taken as evidence that black markets are increasingly unable to compete with legal trade. ${ }^{129}$ There seems no connection between regulation policy, greater availability and consumption among adolescents. ${ }^{130}$

Even in Sweden, which is often cited from prohibitionists as an example of supposedly successful prohibition strategies due to its relatively low prevalence rates, repressive drug policy does not explain consumption rates. ${ }^{131}$ The average amount

126 Rotermann, What has changed since cannabis was legalized?, 31(2) Health Reports (2020) pp. 11-20. Rotermann and Macdonald, Analysis of Trends in the Prevalence of Cannabis Use in Canada, 1985 to 2015, 29(2) Health Reports (2018) pp. 10-20.

127 Rotermann 2020 p. 17.

$128 \quad$ ESPAD 2016 p. 30.

129 Boyd, Cannabis-Legalisierung in Kanada: „Bill C-45“ - Chancen und Probleme [Cannabis Legalisation in Canada: "Bill C-45" - Chances and Problems] in akzept e.V et al. [Federal Association for Acceptable Drug Work et al.], eds. 5. Alternativer Drogen- und Suchtbericht 2018 (5th Alternative Drug and Addiction Report 2018) pp. 59-66 (64).

130 GCDP (Global Commission on Drug Policy), Taking Control: Pathways to Drug Policies That Work, Global Commission on Drug Policy (2014) p.8. http://www.globalcommissionondrugs. org/wp-content/uploads/2016/03/GCDP_2014_taking-control_EN.pdf 01. March 2019; DGSucht 2015 p. 3; Gantner 2016 pp. $55-5 \overline{6}$.

131 Rolles and Murkin. Drug policy in Sweden: a repressive approach that increases harm, Transform (2014) p. 2 http://www.tdpf.org.uk/resources/publications/ drug-policy-swedenrepressive-approach-increases-harm 19. March 2021. 
of cannabis consumed annually by intensive users is second highest in Sweden (363 g; after England/Wales $374 \mathrm{~g}$ ), and lowest in Portugal (184 g). ${ }^{132}$ Not to mention the high mortality rate in Sweden, which reflects only tentative Harm Reduction (HR) efforts. ${ }^{133}$ Obviously, consumption rates are embedded in complex economic, social, and cultural factors.

\subsection{Black markets and costs of prohibition}

The stimulation of the cannabis black market leads to negative consequences for the consumers. ${ }^{134}$ While in Sweden, for example, $52 \%$ of cannabis users state that they can buy other hard drugs where they buy cannabis, only $26 \%$ of Czechs or $14 \%$ of Dutch people state this. The black market is therefore particularly dangerous for young people who simply come into contact with hard drugs and have no information about the composition and active ingredients of the cannabis they buy. Even though Dutch drug policy has often been criticised, evaluations have shown that the approach of separate markets can be seen as positive and that the main objectives of prevention and risk minimisation have been partially achieved. ${ }^{135}$ The use of hard drugs among young people is low, illness and mortality rates among drug addicts are stable and low, and there is no increase in the consumption of soft drugs. Nevertheless, the World Commission points out that the negative effects of the black market cannot be countered by decriminalisation models. ${ }^{36}$ Prohibited production in turn leads to black market problems and organised crime, which is discussed in the Netherlands under the 'back-door problem'. In addition, there remains a risk for the consumer. In order to reduce the harm caused by drug use in the long term, governments must think about suitable market regulation models and consistently regulate access by means of age limits and other security measures.

132 Trautmann, Kilmer and Turnbull, Further insights into aspects of the EU illicit drugs market (Verlag 2013) p. 23.

133 With 92 drug-related deaths per 100,000 inhabitants, Sweden is the European leader after Estonia. European Drug Report 2019. https://www.statista.com/chart/10320/drug-deaths-ineurope/ 03. September 2020.

$134 \quad$ Flöter and Pfeiffer-Gerschel 2012 p. 40.

135 Ooyen-Houben, Gebrauch illegaler Drogen und die niederländische Drogenpolitik: Überblick und Bewertung [Use of illicit drugs and Dutch drugs policy: overview and evaluation], (20) Soziale Probleme) (2009) pp. 57-89; Rolles, Cannabis policy in the Netherlands: moving forwards not backwards, Transform (2014) http://www.tdpf.org.uk/resources/publications/cannabispolicy-netherlands-moving-forwards-not-backwards 01. March 2019.

136 GCDP 2016 p. 33.

137 Cf. Rolles, Nach dem Krieg gegen die Drogen: Modelle für einen regulierten Umgang [After the War on Drugs: Blueprint for Regulation], Transform (2009) p. 23 ff; Stöver and Plenert 2013 p. 38 ff; GCDP 2016 p. 33; GCDP 2018 p. 7. 
The workload of the German police caused by cannabis offences leads to high costs. Since most consumer offences are dismissed $(\$ 31 \mathrm{a}$ BtMG), there are less resources available to prosecute serious offences. Results of a recent survey among police officers in Hamburg show that the attitudes of criminal detectives (contrary to the local police officers) have changed since the 1990s and that prohibition is not considered effective. Although $83.1 \%$ of the officers interviewed in this survey focus on drug trafficking, this does not change the fact that police officers cannot look the other way when dealing with consumer offences. ${ }^{138}$ This is confirmed by the annually increasing number of consumption-related offences in the PKS. ${ }^{139}$ It is therefore not surprising that the Federation of German Criminal Investigators is currently reiterating its demand, which was made for several years now, for a non-repressive drug policy when dealing with consumers. ${ }^{140}$ The main argument is that the resources released could be used to intensify the fight against organised crime in the drugs field. As shown, organised criminal control of production and supply cannot be broken by police means, and a strategy of prohibition promotes it. The cannabis market is large, profitable, organised, and characterised by violence and associated crimes. ${ }^{141}$ Technological innovations raise production volumes and product potency. ${ }^{142}$ The market is $-1 \%$ of Europeans consume cannabis daily ${ }^{143}$ - and was historically not influenced by criminalisation strategies.

Drug consumption does burden healthcare, ${ }^{144}$ but no reliable data yet indicate that regulation elevates that burden. ${ }^{145}$ Moreover, tax revenues from regulated markets create resources for preventive measures that could counteract consumption and exert positive effects on healthcare system. Criminalisation has no demonstrable positive impact on consumption and availability of cannabis. ${ }^{146}$ Lifetime prevalence of cannabis use in Germany, for example, rose until the mid-2000s despite existing

$138 \quad$ Kemme 2018.

$139 \quad$ BKA 2019 p. 154.

140 Site of the Federation of German Criminal Investigators, 31.07.2020. „We are in favour of decriminalising consumers and strengthening the protection of minors". https://www.bdk. de/der-bdk/was-wir-tun/aktuelles/wir-sind-fuer-entkriminalisierung-der-konsumenten-undverstaerkten-jugendschutz 19. March 2021.

$141 \quad$ EMCDDA and Europol 2019 p. 97.

$142 \quad$ Ibid p. 99.

143 Ibid. p. 98.

144 Effertz, Verheyen and Linder, Ökonomische und intangible Kosten des Cannabiskonsums in Deutschland [Economic and intangible costs of cannabis use in Germany] (62) Sucht (2016) pp. 31-41.

$145 \quad$ As claimed by Duttge and Steuer 2014 p.183; 2015, 802, Thomasius in Duttge et al. 2017 p. 39.

146 Haucap, Auch der Fiskus profitiert: Der Nutzen einer Cannabislegalisierung in Deutschland, Akzept e.V., eds. 6. Alternativer Drogenbericht (2019) pp. 112-119. 
prohibition. ${ }^{147}$ According to the Global Commission on Drug Policy ${ }^{148}$ there is no justification for a repressive drug policy. Indeed, drug prohibition is regarded as a failure because black markets generate social damage. ${ }^{149}$

Furthermore, a tightening of prohibition would result in higher costs on the supply side to continue to act undetected on the black market. These costs would also be reflected in prices for consumers. Thus, more resources would have to be spent in illegal markets, whereas legalisation and taxation could lead to revenues on the side of the state. ${ }^{150}$ Regulated markets or even the downgrading of consumption to an administrative offence lead to a massive reduction in the burden on law enforcement agencies. ${ }^{151}$ Even if black markets cannot be eliminated, they can be reduced significantly, ${ }^{152}$ thereby releasing resources for prevention or to fight serious and organised crimes. According to Haucap et al., an amount of 2.66 billion euros can be raised by legalising cannabis, on the one hand through tax revenues and on the other through saved expenditure. ${ }^{153}$

147 Orth, Die Drogenaffinität Jugendlicher in der Bundesrepublik Deutschland 2015. Rauchen, Alkoholkonsum und Konsum illegaler Drogen: aktuelle Verbreitung und Trends. BZgAForschungsbericht. [The drug affinity of young people in the Federal Republic of Germany 2015. Smoking, alcohol consumption and use of illegal drugs: current distribution and trends. BZgA research report.] (Bundeszentrale für gesundheitliche Aufklärung 2016) p. 62.

${ }_{148}$ GCDP (Global Commission on Drug Policy). Advancing Drug Policy Reform: a new approach to decriminalization, Global Commission on Drug Policy (2016). http://www. globalcommissionondrugs.org/wp-content/uploads/2016/11/GCDP-Report-2016-ENGLISH. pdf 01. March 2019. GCDP 2014.

149 GCDP (Global Commission on Drug Policy), Regulation. The Responsible Control of Drugs, Global Commission on Drug Policy (2018) http://www.globalcommissionondrugs.org/wpcontent/uploads/2018/09/ENG-2018_Regulation_Report_WEB-FINAL.pdf 19 March 2021; GCDP 2014, 2016; Stöver and Plenert 2013 p. 44.

150 Scharnhorst and Honecker 2019.

151 Flöter and Pfeiffer-Gerschel, Ökonomische Auswirkungen der Prohibition [Economic Impact of Prohibition] in Entkriminalisierung von Drogenkonsumenten - Legalisierung von Drogen. [Decriminalisation of drug users - legalisation of drugs.], eds. Gerlach and Stöver (Fachhochschulverlag Frankfurt am Main 2013) pp. 33-47 (40 f.); Gaßmann, Die CannabisDiskussion aus der Perspektive von Prävention und Suchthilfe [The cannabis discussion from the perspective of prevention and addiction.] (6) Suchttherapie (2005) pp. 97-101 (100); Kemme, Die Zeit ist reif. Betrachtungen zur Cannabisregulierung unter besonderer Berücksichtigung polizeilicher Belange in Mittler zwischen Recht und Wirklichkeit. Festschrift für Arthur Kreuzer zum 80. Geburtstag, eds. Bartsch et al. (Verlag für Polizeiwissenschaft 2018) pp. 313-348; Stöver and Penert 2013 p. 18; Simon and Hughes, Cannabis und Drogenrecht in Europa: Gesetzeslage, Umsetzung und aktuelle Diskussionen zur Weiterentwicklung, (1) Sucht aktuell (2015) pp. 18-26 (21-23); Pollähne 2016 p. 78.

152 Caulkins et al. 2015 p. 63; Caulkins et al., Considering Marijuana Legalization: Insights for Vermont and Other Jurisdictions (Rand cooperation 2015).

153 Haucap et al., Die Kosten der Cannabis-Prohibition in Deutschland, DICE Consult (2018). 


\section{Political advances}

More than 20 years after the 1994 Federal Constitutional Court decision, the entire German narcotics law was put to test when 122 criminal law professors (the Schildower Kreis) submitted a resolution to the Bundestag, draw legislators' attention to unintended harmful side effects and consequences of criminalising cannabis in 2014. In the resolution, they demanded to check the effectiveness of the drug law. They criticised the unsuccessful criminal prosecution of drug demand and supply and noted that Taliban terrorism in Afghanistan is mainly financed via black market heroin and hashish. This gigantic black market 'generates [...] other subsequent criminal activity and [has] destabilising effects on global financial markets just as [on] national economies'. Science had proven that the danger of drugs would be mastered 'better by health-juridical regulation [...] as well as with adequate youth welfare measures. ${ }^{154}$ The German Society for Addiction Medicine (Deutsche Gesellschaft für Suchtmedizin DGS) joined the resolution in February 2015. The Federation of German Criminal Investigators (Bund Deutscher Kriminalbeamter BDK) ${ }^{155}$ and The New Judges Association (Neue Richtervereinigung) also advocate legalisation. ${ }^{156}$ Thomas Fischer, probably the best-known author of German criminal code commentaries and former presiding judge at the Federal Criminal Court for Criminal Matters, comments the criminal sections on cannabis use as follows: An 'unbiased, rational view (...) should no longer ignore' that 'the prohibition policy of intoxicants has failed in terms of criminal policy, but also criminal law. A society that has 5 percent of its members criminalised because of consumption of intoxicants, while at the same time another 30 percent of the population legally and state-sponsored drinks or smokes itself to death is obviously irrational. ${ }^{15}$

In 2015, opposition fractions in the Bundestag, the Left Party and the Green Party, filed a joint petition to review criminal drug law based on this resolution and to seek support from the Social Party. They drafted a Cannabis Control Bill (Cannabiskontrollgesetz, CannKG) to remove cannabis from criminal restrictions under BtMG and to open

154 The resolution can be found at http://schildower-kreis.de/resolution-deutscherstrafrechtsprofessorinnen-und-professoren-an-die-abgeordneten-des-deutschen-bundestages/ 19. March 2021.

155 The BDK chairman André Schulz claimed that the ban on cannabis was "historically arbitrary and has so far been neither intelligent nor effective": https://www.spiegel.de/panorama/justiz/ cannabis-bund-deutscher-kriminalbeamter-fordert-ende-des-verbots-a-1191381.html 19. March 2021.

156 Opinion of the New Judges Association on the draft of a cannabis control law (CannKG), Bundestag printed matter (BT-Drs.) 18/4204 https://dip21.bundestag.de/dip21/btd/18/042/1804204.pdf 19. March 2021.

157 Fischer (ed.), StGB, 63rd edition (2018), Comment before $\S 52$ StGB. 
a strictly controlled legal market for cannabis. ${ }^{158}$ This would take better account of the protection of minors than before, since it is only in such a market that the ban on selling cannabis to minors can be effectively monitored. A good cannabis policy regulates the cannabis market in such a way that the protection of minors is strengthened, and the risks are reduced as much as possible. Facing opposition from the Christian Party and the Social Party, the draft was rejected in 2017.

In December 2017, the Free Democratic Party joined the cannabis-liberalisationmovement and proposed in a 'small request' to the government for a controlled legal market in cannabis and model projects for its free use. ${ }^{159}$ In its application the FDP parliamentary group also advocated enabling model projects for free cannabis use. The fight against cannabis use by repression had failed. It was therefore time to break new ground in addiction prevention, the group argued. The aim had to be to control the spread of cannabis and to improve public health and youth protection. ${ }^{160}$

In February 2018, the Green Party brought in the Cannabis Control Bill again, claiming it was justified by a failed cannabis drug policy. Cannabis was then Germany's most common illegal drug, consumed by an estimated 3.1 million adult citizens. ${ }^{161}$ In the same month, the parliamentary group of the Left Party also submitted a draft. They also see the cannabis ban policy as a failure. According to their application 'Health protection instead of law enforcement - For a progressive use of cannabis, cannabis is the most commonly used illegal drug. This is countered by a drug policy based on bans, which is ideologically motivated and would ignore the realities of life of the citizens. The group calls for the possession of cannabis for personal use and to strengthen the pillars of drug prevention, advice and treatment in drug policy over the pillar of repression and stigmatisation. ${ }^{162}$ The requests of the opposition groups in the Bundestag were rejected by the government majority.

In February 2020 the fraction of the Social Democratic Party (SPD) in the German Bundestag (coalition partner in the current German government) has also spoken out in favour of a different cannabis policy. It had decided to abandon the previous

158 Bundestag printed matter (BT-Drs.) 18/4204 4. March 2015 http://dip21.bundestag.de/dip21/ btd/18/042/1804204.pdf 19. March 2021.

159 Bundestag printed matter (BT-Drs.) 19/181 5. December 2017 https://dip21.bundestag.de/ dip21/btd/19/001/1900181.pdf 19. March 2021.

160 Bundestag printed matter (BT-Drs.) 19/515 24. January 2018 https://dip21.bundestag.de/dip21/ btd/19/005/1900515.pdf 19. March 2021.

161 Bundestag printed matter (BT-Drs.) 19/819 20. February 2018 http://dip21.bundestag.de/dip21/ btd/19/008/1900819.pdf 19. March 2021.

162 Bundestag printed matter (BT-Drs.) 19/832 21. February 2018, https://dip21.bundestag.de/ dip21/btd/19/008/1900832.pdf 19. March 2021. 
cannabis ban policy in Germany, the fraction stated. ${ }^{163}$ The possession of small amounts of cannabis for personal consumption should no longer be prosecuted and instead only be treated as an administrative offence. Model projects should be made possible to test legal and regulated supply of cannabis to consumers. Several applications of German cities ${ }^{164}$ in this regard have so far been regularly rejected by the responsible Federal Institute for Medicinal Products and Medical Devices (Bundesinstitut für Arzneimittel und Medizinprodukte (BfArM") due to the existing legal situation. ${ }^{165}$

The coalition partner in the current government, the Christian Democratic Party (CDU/CSU), sticks with the argument that cannabis is a gateway drug and damages the brain. ${ }^{166}$ As for the German population according to a poll by Infratest Dimap on behalf of the German association Deutscher Hanfverband in the year 2019 44\% of Germans are in favour of legalisation of cannabis for adults. ${ }^{167}$

\section{New Submission order to the German Federal Constitutional Court in April 2020}

In addition to the legislative initiatives, there are also current efforts by the advocates of decriminalisation to achieve their goals by establishing the unconstitutionality of the criminal norms. In April 2020, the Criminal District Court of Berlin-Bernau justified a submission order to the Federal Constitutional Court (BVerfG) with the fact that the prohibition of cannabis is unconstitutional. ${ }^{168}$ This is the conclusion reached by criminal judge Andreas Müller from the Bernau district court (near Berlin). Does a German court consider a law, the validity of which is important for the decision unconstitutional, it suspends the proceedings and gets the decision of the Federal Constitutional Court.

163 Position Paper of the fraction of the Social Democratic Party (SPD) in the German Bundestag, $11^{\text {th }}$ of February 2020, https://www.spdfraktion.de/system/files/documents/positionspapiercannabis-neue-wege-gehen-20200211.pdf 19. March 2021.

164 Düsseldorf, Münster, Bremen, Berlin Kreuzberg and most recently the state of Berlin.

165 The application of Berlin was rejected in April 2020, Press release of the State of Berlin: https:// www.berlin.de/aktuelles/berlin/6136312-958092-bundesinstitut-lehnt-cannabismodellversu. html 19. March 2021.

166 The drug commissioner of the federal government from the CSU also takes this view https:// www.drogenbeauftragte.de/ 19. March 2021.

167 Poll of the Infratest Dimap on behalf of Deutscher Hanfverband in 2019: https://hanfverband. de/sites/default/files/2019.09.02_hanfverband_cannabis_graf.pdf 19. March 2021.

168 Js 7322/19 (346/19) Criminal District Court of Berlin-Bernau, decision in criminal matters of 18. September 2019. http://www.ag-bernau.brandenburg.de/media_fast/4190/ Vorlagebeschluss\%20vom\%2020.04.2020\%20-\%20anonymisiert\%20-.16675354.pdf March 2021. 
In this case, a 24-year-old mechanical engineering student purchased 2,6 $\mathrm{g}$ of cannabis resin in the Görlitzer Park (Berlin) and was subsequently subjected to a police check. Since the young man already had been taken with resin, the prosecutor refused to dismiss the case and demanded a fine of 150 euros.

For a new application to the Federal Constitutional Court to be authorised, the district court must prove that there have been 'new facts' since 1994, when the Federal Constitutional Court ruled on the question for the first time. ${ }^{169}$ In 2004 , when the same judge Müller from the Bernau district court had already filed such a submission order, the court had found it to be inadmissible, among other reasons, because new facts 'which would enable a decision that diverged from the earlier decision of the Federal Constitutional Court' had not been stated. ${ }^{170}$ Among other things, judge Müller now states that there are now indications that the dangerousness of cannabis is to be assessed differently than before: 'The clearest and most recent expression of the re-evaluation of the dangerousness of cannabis is found in the critical report on the current classification of cannabis by the Standard Agreement on Narcotics, published in 2018 by the WHO Expert Committee on Drug Dependence. ${ }^{171}$ The committee submitted a letter to the Secretary General of the United Nations, António Guterres, with reference to Art. 3 of the Single Convention on Narcotic Drugs, which noting that preparations based on pure Cannabidiol (CBD) should no longer be listed in international drug control agreements. ${ }^{172}$

Further, Müller refers to more recent evidence, according to which the 'general assumption that cannabis use has a deterioration in mental health', cannot be proven. 'It can be shown that stronger problematic people consume particularly frequently, evidence of a harmful substance effects of cannabis, however, cannot be found' he states. It should also be noted, 'that in light of the millions relatively few are treated in outpatient or inpatient settings because of the main diagnosis cannabis. ${ }^{173}$

1712 Cs 226 Js 7322/19 (346/19) p. 14 (Criminal District Court of Berlin-Bernau, decision in criminal matters of 18 September 2019). http://www.ag-bernau.brandenburg.de/media fast/4190/Vorlagebeschluss\%20vom\%2020.04.2020\%20-\%20anonymisiert\%20-.16675354. pdf 19. March 2021.

172 Letter of the WHO Expert Committee on Drug Dependence from 2019, https://faaat.net/wpcontent/uploads/ECDD-cannabis-final-outcome.pdf 19. March 2021.

1732 Cs 226 Js 7322/19 (346/19) p. 18 (Criminal District Court of Berlin-Bernau, decision in criminal matters of 18. September 2019) http://www.agbernau.brandenburg.de/media fast/4190/Vorlagebeschluss\%20vom\%2020.04.2020\%20-\%20anonymisiert\%20-.16675354. pdf 19. March 2021. 
Whether the 140-page submission order now passes the hurdle of the admissibility test, is considered open by observers. Essentially it depends on whether the District Court has presented enough facts to convince the Federal German Court that a new situation has arisen on the subject of cannabis that could be considered legally.

\section{Summary and conclusions}

The current German legal system of cannabis control is based on strict prohibition of cannabis outside medical or scientific use. As in many other western countries, an increasing number of German scientists and citizens and therefore also a growing number of political parties are of the opinion that the Narcotics Act in Germany needs an urgent review (see section 2).

As shown above, there are numerous new studies on cannabis, making it one of the best researched drugs. Studies classify the health and social risk of cannabis as low, especially for recreational use by adults (see section 3.1 and 3.2). It can be regarded as empirically proven that the recreational use of cannabis is relatively harmless compared to the currently legal drugs alcohol and nicotine.

As with any other drug, children and young people are particularly vulnerable and must be protected (see Section 3.3). The use of cannabis in childhood and adolescence can have both physical and psychological consequences. But, the results of the present paper do not allow the conclusion that prohibition-oriented drug policies prevent young people of using drugs or that more liberal policies lead to an increase in prevalence rates. Although prohibitionists claim that there is a link between national drug strategy and consumption rates, there is no empirical evidence for such a correlation. The comparison of countries with different drug policy approaches reveals that cannabis use among young people seems to be influenced by a number of other factors. Even in Sweden, which is often cited from prohibitionists as an example of supposedly successful prohibition strategies due to its relatively low prevalence rates, repressive drug policy does not explain consumption rates. Decriminalisation has neither increased consumption rates in Portugal nor reduced the age of onset in the Czech Republic. ${ }^{174}$ The decisive factors are ancillary, including measures geared to prevention, addiction therapies, and reducing damage.

174 Červený, Chomynová, Mravčík et al. 'Cannabis decriminalization and the age of onset of cannabis use'. International Journal of Drug Policy, (43) (2017) pp. 122-129 (128). 
Consumers look for their own ways. In this respect, the demand side - not the supply side - is identified as important source of problems and drug policy starting point. ${ }^{175}$ In its reports, the Global Commission on Drug Policy makes it more than clear that states must finally abandon the wishful thinking of a drug-free society by prohibition; prohibitive drug policy models have failed because they can neither prevent nor reduce consumption and dependence. ${ }^{176}$ In this sense, the German Society for Addictive Medicine, ${ }^{177}$ the German Head Office for Addiction Issues ${ }^{178}$ and, as already mentioned, a majority of professors of criminal law in Germany (the Schildower Kreis) recommend that the German Narcotics Act be reviewed, as the law's goal of excluding the misuse of narcotics and the development or maintenance of narcotic dependence as far as possible has not been achieved. In addiction medicine, the dogma of abstinence already fell 20 years ago, so that it is primarily a matter of ensuring the healthiest possible survival, reducing consumption and extending abstinent periods. ${ }^{179}$

The stimulation of the cannabis black market leads to negative consequences for the consumers. ${ }^{180}$ The black market is particularly dangerous for young people who simply come into contact with hard drugs and have no information about the composition and active ingredients of the cannabis they buy. Even though Dutch drug policy has often been criticised, evaluations have shown that the approach of separate markets can be seen as positive and that the main objectives of prevention

175 Raschke, Freigabe illegaler Drogen: Ethisch geboten oder unverantwortlich? - Pro (Release of Illicit Drugs: Ethical Command or Irresponsible Attitude? - Pro), Suchttherapie, (09) (2008) pp. 164-169 (167).

176 Cf. GCDP, 2014, 2016, GCDP. The World Drug Perception Problem. (2017) http://www. globalcommissionondrugs.org/wp-content/uploads/2018/01/GCDP-Report-2017_PerceptionsENGLISH.pdf 01. March 2019. GCDP 2018, 2019, GCDP, Enforcement of Drug Laws. Refocusing on Organized Crime Elites. (2020) https://www.globalcommissionondrugs.org/wpcontent/uploads/2020/06/2020report_EN_web_100620.pdf 03. September 2020.

177 DGS (Deutsche Gesellschaft für Suchtmedizin e.V.), Warum das Betäubungsmittelgesetz (BtMG) aus suchtmedizinischer Sicht auf den Prüfstand gehört. [Why the Betäubungsmittelgesetz (BtMG) belongs from the point of view of addiction medicine to the test.] Suchttherapie, (15) (2014) p. 49.

178 DHS (Deutsche Hauptstelle für Suchtfragen e.V.) (2015). Cannabispolitik in Deutschland. Maßnahmen überprüfen. Ziele erreichen. [Cannabis policy in Germany. Check measures. Achieve goals.] http://www.dhs.de/fileadmin/user_upload/pdf/news/Cannabispolitik_in_ Deutschland.pdf 01. March 2019.

$179 \quad$ DGS 2014 p. 49.

$180 \quad$ Flöter and Pfeiffer-Gerschel 2012 p. 40. 
and risk minimisation have been partially achieved. ${ }^{181}$ The use of hard drugs among young people is low, illness and mortality rates among drug addicts are stable and low, and there is no increase in the consumption of soft drugs. Nevertheless, the World Commission points out that the negative effects of the black market cannot be countered by decriminalisation models. ${ }^{182}$ Prohibited production in turn leads to black market problems and organised crime, which is discussed in the Netherlands under the 'back-door problem'. In addition, there remains a risk for the consumer. In order to reduce the harm caused by drug use in the long term, governments must think about suitable market regulation models and consistently regulate access by means of age limits and other security measures. ${ }^{183}$

It is sometimes argued by prohibitionists in Germany that repression is after all only one pillar of a balanced cannabis policy, which already (sufficiently) takes into account the other pillars of prevention, treatment and HR. Only in recent years, a number of therapy measures and intervention programmes have been established in the cannabis field. However, there is still a lack of adequate consideration of feasible HR measures. ${ }^{184}$ In Germany, the implementation of both individual and structural HR approaches is very limited. ${ }^{185}$ It is not - as is sometimes claimed - predominantly the law enforcement agencies that place young people in programmes. Rather, the illegality of cannabis makes access to early intervention programmes via other potential placement partners such as schools, parents, companies, youth welfare services, vocational preparation courses or youth leisure centres more difficult, ${ }^{186}$ so that many young people in need of help remain unreached. In addition, it is known from addiction aid that especially socially disadvantaged and psychologically vulnerable young people, as a result of prohibition, reach criminal milieus faster than

181 Ooyen-Houben, Gebrauch illegaler Drogen und die niederländische Drogenpolitik: Überblick und Bewertung [Use of illicit drugs and Dutch drugs policy: overview and evaluation], Soziale Probleme, (20) (2009) pp. 57-89; Rolles, Cannabis policy in the Netherlands: moving forwards not backwards. Transform (2014) http://www.tdpf.org.uk/resources/publications/cannabispolicy-netherlands-moving-forwards-not-backwards 01. March 2019.

182 GCDP 2016 p. 33.

183 Cf. Transform. Nach dem Krieg gegen die Drogen: Modelle für einen regulierten Umgang 2009 p. 23 ff; Stöver and Plenert 2013 p. 38 ff; GCDP 2016 p. 33; GCDP 2018 p. 7.

184 Bücheli, Schadensminimierung und Cannabis: Ist Safer Use möglich?, Suchtmagazin (2), (2014) pp. 47-51; Manthey, Stöver and Meyer-Thompson, Cannabis und Schadensminderung in Deutschland (Cannabis and Harm Reduction in Germany), Suchttherapie, (19) (2018) pp. $148-158$.

185 Manthey et al. 2017.

186 DGSAS (Deutsche Gesellschaft für Soziale Arbeit in der Suchthilfe) (2015). Stellungnahme „Erfahrungen in der Frühintervention bei jugendlichen Cannabiskonsumenten “. [Statement „Experiences in Early Intervention in Juvenile Cannabis Consumers"] www.dgsas.de/ downloads/Stellungnahme\%20Cannabis\%20BMG_DGSAS_23.2.15.pdf 03. March 2018, p. 2; Gantner 2016 p. 56. 
others. ${ }^{187}$ A cannabis policy that continues to insist on the necessity of the pillar of repression will not be able to protect the health of consumers sufficiently in the long term. Open, targeted prevention work will be hindered; people will be discouraged from seeking help. With regard to alcohol and nicotine, it is already known that regulated markets offer the most effective protection when the framework conditions are adapted with stricter rules and increased educational work. ${ }^{188}$ Positive trends in alcohol and cigarette consumption among young people can currently be observed. ${ }^{189}$ According to youth researchers, the image of these drugs has deteriorated, which suggests a connection with educational campaigns.

It is certainly true that the impact of a market regulating all drugs cannot yet be conclusively assessed. Moreover, the European Monitoring Centre for Drugs and Drug Addiction rightly points out that developments and evaluations in other parts of the world need not be directly transferable to the European context. ${ }^{190}$ However, a proportionality assessment with regard to cannabis prohibition leads to a clear result. The damage to society as a whole caused by prohibition can only be effectively countered by a regulated market, especially for the protection of young people. Overall, a strictly regulated market would be expected to provide positive economic, social and health incentives.

Currently two approaches of changing drug policy with regard to cannabis are being pursued: One approach regards legislative initiatives by political parties to decriminalise the use of cannabis. Already several times in recent years a Cannabis Control Bill aiming to liberalise cannabis use has been introduced to German Parliament, still lacking a political majority. Nevertheless the number of political parties in favour of a changed policy increased during the last years. A second approach can be found in the submission order to the Federal Constitutional Court presenting 'new facts' with the aim of declaring the current prohibition (German Narcotics Act) law unconstitutional. Such order was filed to the Federal Constitutional Court in 2020. Both approaches are based on new scientific knowledge on the harms of cannabis use physically, psychically and economically ('new facts').

While chances of success of the current application to the Federal Constitutional Court do not appear predictable, the political climate could change in the near future towards a change in the German Narcotic Act. In Germany - as in many other western countries - drug policy reform towards cannabis seems increasingly likely.

190 EMCDDA 2017 p. 12. 